\title{
Small Intestinal Sarcoma
}

National Cancer Institute

\section{Source}

National Cancer Institute. Small Intestinal Sarcoma. NCI Thesaurus. Code C5335.

A malignant soft tissue neoplasm that arises from the small intestine. Representative examples include leiomyosarcoma, angiosarcoma, and Kaposi sarcoma. 